\title{
Influencia del medio ambiente en el deterioro de materiales calizos: estudios mediante porosimetría de mercurio
}

\section{Influence of the environment on weathering of limestone: study through mercury porosimetry}

\author{
M. I. SÁNCHEZ DE ROJAS ${ }^{(*)}$, N. GARCÍA ${ }^{(*)}$ y M. FRíAS ${ }^{(*)}$. Drs. en Ciencias Químicas \\ ${ }^{(*)}$ Instituto de Ciencias de la Construcción "Eduardo Torroja", ${ }^{(*)}$ Laboratorio Control de Materiales CLAR Rehabilitación
}

Fecha de recepción: 4-IX-98

Fecha de aceptación: 3-XI-98

ESPAÑ A

\section{RESUMEN}

Los procesos fisico-químicos de degradación de los materiales de construcción en general, y de los materiales pétreos en particular, obedecen a distintas causas, como son: composición, morfología, textura, orientación en el edificio, y principalmente de la interacción con el medioambiente.

Los materiales calizos, por su composición química, pueden sufrir alteraciones al entrar en contacto con un medio agresivo, como puede ser el agua de lluvia o niebla contaminada con gases, que actúan disolviendo la roca y provocando costras por precipitación de sales.

Este trabajo tiene como base el estudio de un material calizo, procedente de un edificio situado en una zona céntrica de Madrid, utilizando porosimetría de mercurio, entre otras técnicas instrumentales.

\section{SUMMARY}

The physico-chemical processes of decay in building materials and, particularly those affecting petreum materials, obey to different causes as composition, morphology, texture, the orientation of the material in the building and, mainly, its interaction with the environment.

Because of their chemical composition, limestone materials may undergo alterations when they are in contact with aggresive media. Rain water or fog contain gases that may dissolve the stone provoking crusts due to salts precipitation.

This work is based in the study of the decay processes of a limestone material from a building placed at Madrid. Mercury porosimetry technique (among others) is used in this study.

\section{INTRODUCCIÓN}

Son numerosos los trabajos realizados sobre alteraciones de materiales relacionados con el medio ambiente; en ellos se pone en evidencia cómo influye el entorno en su durabilidad, y el efecto ocasionado por los posibles mecanismos de ataque que tienen lugar (1) (2). Las técnicas empleadas en estos estudios son diferentes y todas ellas sirven para destacar algún cambio provocado por el deterioro en las propiedades iniciales del material (3) (4) (5).

\section{INTRODUCTION}

There is a number of works describing materials alteration due to environment and evidencing the influence of the surroundings on their durability, as well as the effect of the possible attack mechanisms that could take place (1) (2). The techniques used in these studies are different, but all of them have evidenced some change, caused by deterioration, in the initial properties of the material (3) (4) (5). 
En este trabajo, se investiga el efecto producido por la contaminación ambiental en materiales calizos procedentes de un edificio de Madrid, construido a principios de siglo y situado en una zona céntrica de esta ciudad.

Los estudios se realizan mediante porosimetría de mercurio, empleando además otras técnicas adicionales como difracción de rayos $\mathrm{X}$, espectroscopía IR, microscopía electrónica de barrido y cromatografia iónica.

\section{ESTUDIOS EXPERIMENTALES}

Las muestras analizadas pertenecen a distintas localizaciones del edificio, construido con materiales calizos de diferentes tipologías.

Para comprobar la influencia de los agentes contaminantes en el deterioro de estos materiales se lleva a cabo un análisis en profundidad, de forma que se seleccionan muestras externas e internas de los bloques de piedra de fachadas y esculturas, con lo que se evalúa el avance de la degradación.

En concreto se estudian 10 testigos, de los cuales se analizan zonas externas e internas:

* 10 muestras procedentes de las zonas externas (1e, $2 \mathrm{e}, 3 \mathrm{e}, 4 \mathrm{e}, 5 \mathrm{e}, 6 \mathrm{e}, 7 \mathrm{e}, 8 \mathrm{e}, 9 \mathrm{e}$ y $10 \mathrm{e}$ )

* 10 muestras extraídas en profundidad ( $1 \mathrm{i}, 2 \mathrm{i}, 3 \mathrm{i}$, $4 i, 5 i, 6 i, 7 i, 8 i, 9 i$ y $10 i)$

En las muestras se realiza una preparación previa para llevar a cabo los ensayos previstos. La forma de preparación depende del tipo de análisis a efectuar y consiste, principalmente, en el troceado o molienda de alguna parte de las mismas.

\subsection{Estudio de los materiales por porosimetría de mercurio}

Con esta técnica instrumental se pretende poner en evidencia el deterioro de los materiales, mediante las variaciones observadas en la porosidad y distribución de los tamaños de poro (6) (7) (8), en muestras externas e internas de los bloques de piedra extraídos en obra.

El Equipo utilizado es un Porosímetro de Mercurio, marca Micromeritics, modelo Autopore II 9220, que alcanza una presión de $414 \mathrm{MPa}$ (60.000 psia).
This work describes a research on the effect environmental pollution has on the limestone belonging to a building located in the center of Madrid and built at the beginning of the 20th century.

This research has been carried out through mercury porosimetry. Additional techniques as X ray diffraction, IR spectroscopy, scanning electron microscopy and ion chromatography have been also used.

\section{EXPERIMENTAL STUDIES}

Samples analysed were extracted from different zones of that building, which had been built with differents types of limestone.

In order to prove the influence of pollutant agents on the decay of these materials, samples taked from the stone blocks located on the surface, others from deep façade internal, and others from sculptures are analysed. This research allows an evaluation of the degradation phenomena.

In this specific research 10 samples from the external and internal areas have been:

* 10 samples from the external zones (1e, $2 e, 3 e, 4 e$, $5 e, 6 e, 7 e, 8 e, 9 e$ and $10 e)$

* 10 samples taked from the inner part of the blocks (1i, 2i, 3i, 4i, 5i, 6i, 7i, 8i, 9i and 10i)

To carry out the test samples must be prepared before the analysis. The kind of preparation depends on the kind of analysis to be made, and mostly consists in breaking into pieces some specific area of the stone material, and grinding some of them.

\subsection{Study of materials through mercury porosimetry}

This instrumental technique allows the observation of the decay of materials through variations in porosity and pore size distribution (6) (7) (8) in sample taked from the surface and from the internal zone of stone blocks of the buiding.

The equipment consists in a mercury porosity meter; the brand is Micromeritics, model Autopore II 9220, which can reach $414 \mathrm{MPa}$ of pressure (60.000 psia). 
Para efectuar el ensayo, los materiales son cortados hasta alcanzar las dimensiones adecuadas. En las muestras externas, se eliminan las costras superficiales, de forma que se analiza el material pétreo que se encuentra debajo de estas capas alteradas.

* Resultados Experimentales

En la Tabla I se recogen los valores de porosidad correspondientes a cada una de las muestras analizadas: muestras externas $(\mathrm{Xe})$ y muestras extraídas del interior de los bloques (Xi). De igual forma, en la Figura 1, se representan las curvas de distribución de tamaño de poros.
At the beginning of tests, materials are cut until the right size is reached. On external specimens the superficial crust is scratched out in order to analyze the stone located under this decayed layer.

\section{* Experimental Results}

In Table I the porosity values corresponding to every one of the analyzed samples are shown: external (Xe) and internal samples (Xi). Also in Figure 1 pore-size distribution curves are represented.

TABLA I (TABLE I)

Porosidad de las muestras (porosity of the samples)

\begin{tabular}{|c|c|c|}
\hline MUESTRA (SAMPLE) & $\begin{array}{l}\text { POROSIDAD (\%) } \\
\text { POROSITY }(\%)\end{array}$ & $\begin{array}{c}\text { DIAMETRO DE PORO } \\
\text { MAS FRECUENTE }(\mu \mathrm{m}) \\
\text { (MOST FREQUENT PORE } \\
\text { DIAMETER }(\mu \mathrm{m}))\end{array}$ \\
\hline $1 \mathrm{e}$ & 15,57 & 0,2 \\
\hline $1 \mathrm{i}$ & 18,09 & 0,4 \\
\hline $2 \mathrm{e}$ & 15,73 & $0,3 / 0,01$ \\
\hline $2 \mathrm{i}$ & 16,92 & $1 / 0,2 / 0,01$ \\
\hline $3 e$ & 20,26 & 0,6 \\
\hline $3 i$ & 22,99 & 1 \\
\hline $4 \mathrm{e}$ & 19,71 & $20 / 1 / 0,1$ \\
\hline $4 i$ & 19,58 & $10 / 1 / 0,1$ \\
\hline $5 e$ & 19,49 & 0,6 \\
\hline $5 i$ & 19,93 & 0,6 \\
\hline $6 e$ & 17,96 & $6 / 1 / 0,2$ \\
\hline $6 i$ & 17,94 & $6 / 1 / 0,2$ \\
\hline $7 e$ & 18,89 & $10 / 1$ \\
\hline $7 i$ & 20,63 & $10 / 1$ \\
\hline $8 e$ & 20,43 & $6 / 0,8 / 0,2$ \\
\hline $8 \mathrm{i}$ & 20,79 & 0,6 \\
\hline $9 e$ & 10,82 & 0,3 \\
\hline $9 i$ & 13,92 & 0,3 \\
\hline $10 \mathrm{e}$ & 17,65 & 0,3 \\
\hline $10 \mathrm{i}$ & 17,12 & 0,3 \\
\hline
\end{tabular}



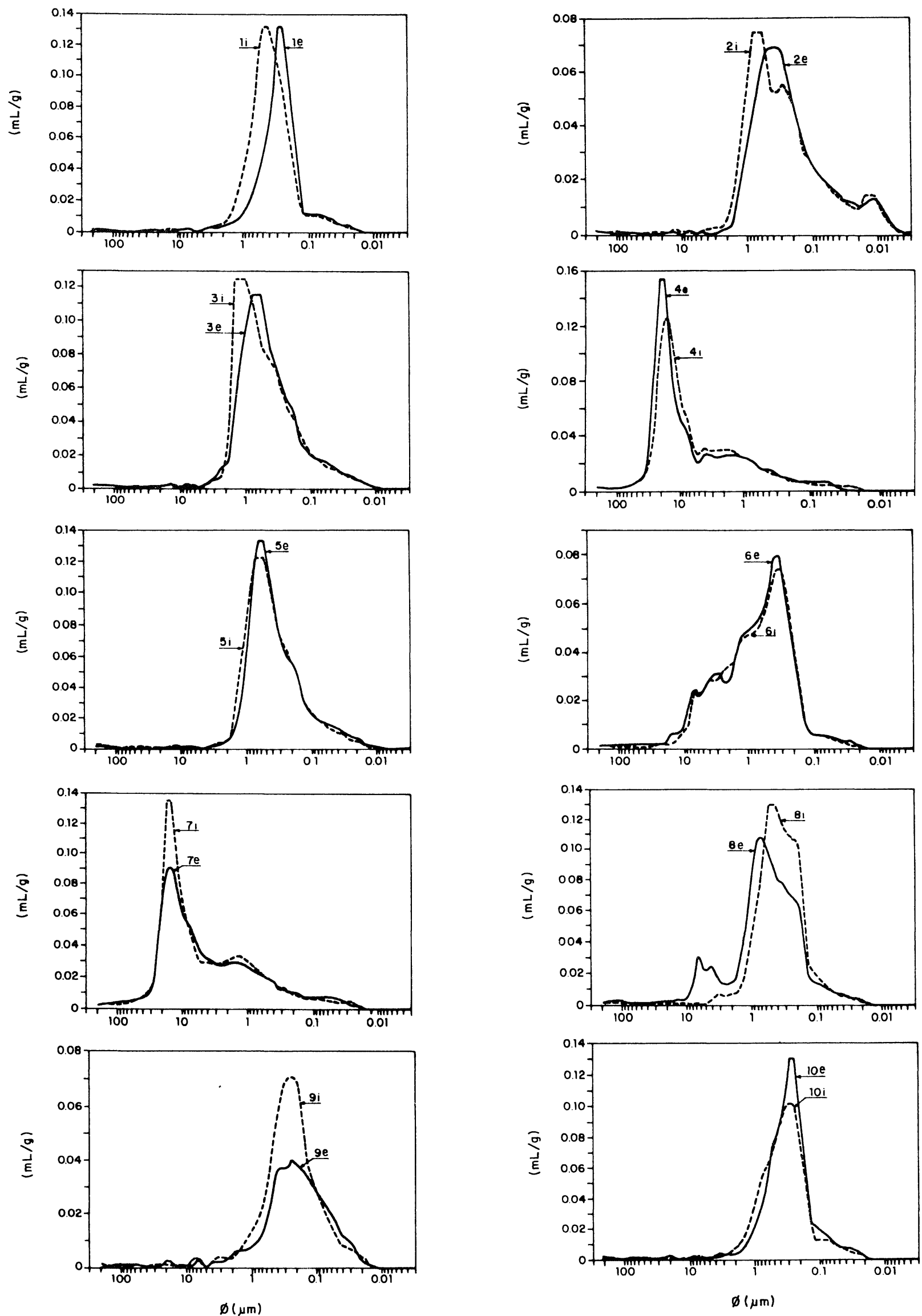

Figura 1.- Distribución de poros.

Figure 1.-Pore distribution. 
A la vista de lo resultados se pueden establecer dos tendencias:

* Una disminución de la porosidad en las muestras exteriores en relación con las interiores, al mismo tiempo suele producirse una disminución en los tamaños de poro (disminución del diámetro donde aparece el máximo de densidad de tamaños de poro), o también un menor contenido de poros de menor tamaño (disminución de la altura del máximo de densidad de tamaños de poro). Este hecho puede deberse a la colmatación de los poros por sales en las zonas externas que se encuentran inmediatamente debajo de la costra superficial.

* Diferencias no muy significativas, lo que indica que el deterioro de las muestras no es muy pronunciado y, una vez eliminadas las costras producidas por la acción de los agentes contaminantes, el material pétreo no ha sufrido cambios importantes en su estructura.

\subsection{Difracción de Rayos $x$}

En los materiales pétreos, el estudio se lleva a cabo en las muestras externas (Xe) y en muestras extraídas del interior de los bloques (Xi).

Los análisis en las muestras externas, al igual que en los estudios por porosimetría de mercurio, se realizan una vez eliminadas las costras superficiales de las mismas, por lo que se analiza el material pétreo simplemente.

\section{* Resultados experimentales}

En la Figura 2 se representan algunos de los difractogramas más significativos. Las diferencias observadas, entre zonas internas y zonas externas, son mínimas. Cabe destacar que, una vez eliminadas las costras superficiales, los materiales analizados no presentan picos de difracción que pongan de relieve la presencia de sales en el interior del material.

\subsection{Estudio de las sales solubles}

Con estos ensayos se identifica la naturaleza y cantidad de sales depositadas en el exterior de los materiales y también en el interior de los bloques, de forma que se detecte el alcance del deterioro producido por la contaminación ambiental.

Las muestras necesarias para efectuar el ensayo de sales solubles, proceden de zonas en las que existen costra y material pétreo conjuntamente; es decir, no se realiza una separación previa como tenía lugar en los ensayos anteriores. La proporción entre costra y piedra
According with the results, it is possible to define to general two trends:

* A porosity decrease is observed in external parts compared to internal ones; at the same time it is frequent to find a decrease of the pore size (decrease of the pore diameter which corresponds with the maximum value of pore-size) and also less content of small pores (decrease of the maximum height). This fact can be due to salts clogging the pores in external areas located just under the superficial crust.

* Porosity differences observed are not very significant, which indicates that deterioration of samples is not very deep, and once the crust due to pollutant agents is removed, stone does not show important changes in its structure.

\subsection{Ray diffraction}

The study of the stone is carried out on external specimens $(\mathrm{Xe})$ and those taked from the inside of the stone blocks $(\mathrm{Xi})$.

Analyses of Xe specimens, same as in mercury porosimetry studies, have been carried out once the surface crust is scrapped out in order to analyse just the stone.

\section{* Experimental Results}

Some of the results of the most significant diffractograms are represented in Figure 2. The differences observed on them are minimal comparing external and internal zones. It has to be pointed out that once the surface crust is removed, the material does not show any diffraction peak that could indicate the presence of salts inside the material.

\subsection{Study of soluble salts}

Through these tests the nature and amount of salts deposited in the external zones and also in the materials depth are identified. The reach of the weathering degree of limestone, caused by environmental pollution can be measured in this way.

Samples for the soluble salts test come from areas where stone and crust stand together; this means that no previous separation has been made as in tests before. Proportion between crust and stone cannot be kept equal, since it depends on the thickness of the 

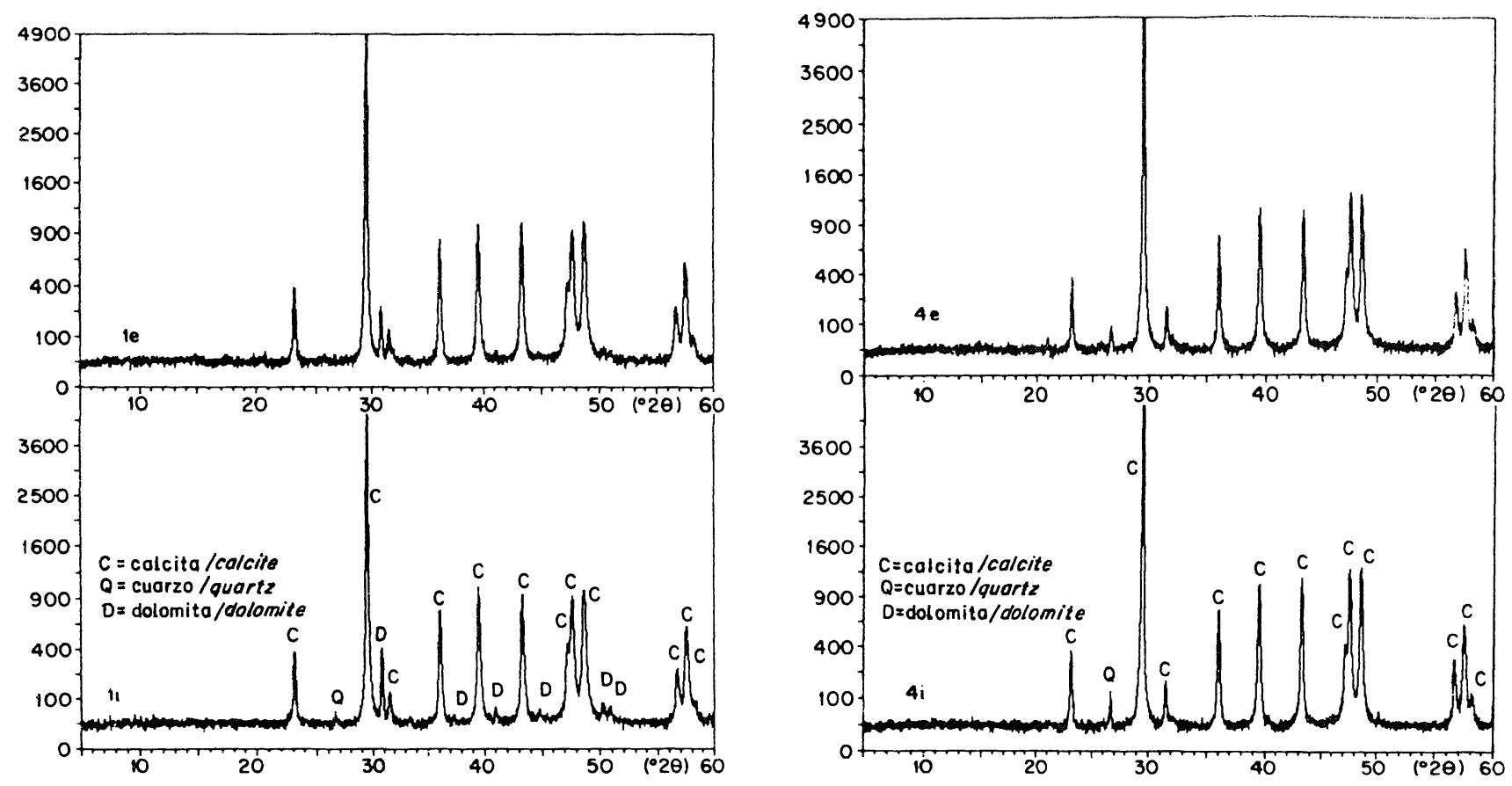

Figura 2.- Difracción de Rayos X.

Figure 2.- X Ray Diffraction.

no puede mantenerse del todo fija, ya que depende del espesor de la capa superficial, por ello, los datos, aunque son representativos, dependerán de la muestra en cuestión.

El análisis consiste en poner, aproximadamente, un gramo de muestra, una vez molida, en contacto con agua desionizada, durante 30 minutos, al cabo de los cuales, se procede al filtrado de la misma. El líquido se recoge y se lleva a un volumen fijo, $250 \mathrm{ml}$, y en él, mediante Cromatografia Iónica, se analizan los iones cloruro, nitrato y sulfato, respectivamente.

* Resultados Experimentales

En la Tabla II se recogen los resultados de los análisis de sales solubles, realizados por Cromatografía Iónica.

De los iones analizados, solamente resulta significativo el contenido en sulfatos, los demás se encuentran en concentraciones muy bajas o no son detectados.

En líneas generales, como es de esperar, las muestras más externas presentan un mayor contenido en sales, sulfatos principalmente, que las muestras obtenidas del interior de los bloques. Esto se debe al efecto que los agentes contaminantes tienen sobre la piedra, con la formación de costras superficiales, compuestas por yeso en su mayor parte. superficial layer and, for this reason, even if data are representative, the results depend on each specific material.

The analysis consists in getting approximately one gram of material and, once it has been grinded, soaking it in deionized water for 30 minutes. Subsequently, water is filtered and the volume is brought to $250 \mathrm{ml}$. Then chlorides, nitrates and sulphates are analysed through Ion Chromatography.

\section{* Experimental Results}

Table II shows soluble salts contents obtained from the different samples.

These results show clearly the presence of sulphates in the crust while others ones are detected in very low concentrations or concentrations that are not detectable.

As expected, the external specimens have a higher salts content (mainly sulphates) than those that have been extracted from the inward surface. This is due to the effect of the pollutant agents on the stone, which causes the formation of the superficial crusts most of them of gypsum. 
TABLA \| (TABLE II)

Análisis cuantitativo de aniones en sales solubles en agua por Cromatografía Iónica (Quantitative analysis of soluble salt anions in water through lon Chromatography)

\begin{tabular}{|c|c|c|c|}
\hline MUESTRA (SAMPLE) & $\mathrm{Cl}^{-}(\%)$ & $\mathrm{NO}_{3}^{-} \quad(\%)$ & $\mathrm{SO}_{4}=(\%)$ \\
\hline $1 e$ & $<0,01$ & $<0,01$ & 0,83 \\
\hline $1 \mathrm{i}$ & -- & -- & 0,06 \\
\hline $2 \mathrm{e}$ & 0,02 & $<0,01$ & 1,55 \\
\hline $2 \mathrm{i}$ & 0,02 & $<0,01$ & 0,05 \\
\hline $3 e$ & $<0,01$ & $<0,01$ & 1,31 \\
\hline $3 i$ & $<0,01$ & $<0,01$ & 0,06 \\
\hline $4 e$ & $<0,01$ & $<0,01$ & 0,36 \\
\hline $4 i$ & -- & $-\cdots$ & 0,01 \\
\hline $5 e$ & --- & -.. & 1,14 \\
\hline $5 i$ & $<0,01$ & $<0,01$ & 0,04 \\
\hline $6 e$ & $<0,01$ & $<0,01$ & 0,36 \\
\hline $6 i$ & --- & -- & 0,05 \\
\hline $7 e$ & $<0,01$ & -- & 2,98 \\
\hline $7 i$ & --- & -- & 0,22 \\
\hline $8 \mathrm{e}$ & --- & -- & 0,27 \\
\hline $8 i$ & $\cdots--$ & -- & $<0,01$ \\
\hline Se & --- & --- & 0,01 \\
\hline $9 i$ & $-\cdots$ & $<0,01$ & 0,25 \\
\hline $10 \mathrm{e}$ & $<0,01$ & -- & 2,60 \\
\hline $10 i$ & --- & $<0,01$ & 0,02 \\
\hline
\end{tabular}

\subsection{Espectroscopia $\mathbb{R}$}

El análisis por Espectroscopía IR se realiza en la parte externa de las muestras, en concreto en la costra más superficial.

\section{* Resultados Experimentales}

En los espectros correspondientes (Figura 3) pueden observarse las bandas características de la calcita, como componente principal de la caliza $(1795,1435$, 877 y $\left.712 \mathrm{~cm}^{-1}\right)$ y del yeso $(3550,3400,1620,1140$ 1120,669 y $\left.600 \mathrm{~cm}^{-1}\right)$. Se trata de yeso procedente de la reacción del calcio de la caliza con los iones sulfato generados por agentes contaminantes (oxidación e hidrólisis del $\mathrm{SO}_{2}$ ).

\subsection{IR Spectroscopy}

IR Spectroscopy analysis was carried out on supericial crust of the limestones.

\section{* Experimental Results}

In the corresponding spectra (Figure 3) can be observed the characieristic bands of the calcite as main component of the limestone $\left(1795,1435,877,847\right.$ and $712 \mathrm{~cm}^{-1}$ ) and, the crusts which are formed mainly by gypsum $\left(3550,3400,1620,1140-1120,669\right.$ and $\left.600 \mathrm{~cm}^{-1}\right)$ owing to the reaction between calcium from the limestone and the sulphate ions generated by the pollutant agents (oxidation and hydrolisis reaction of $\mathrm{SO}_{2}$ ). 


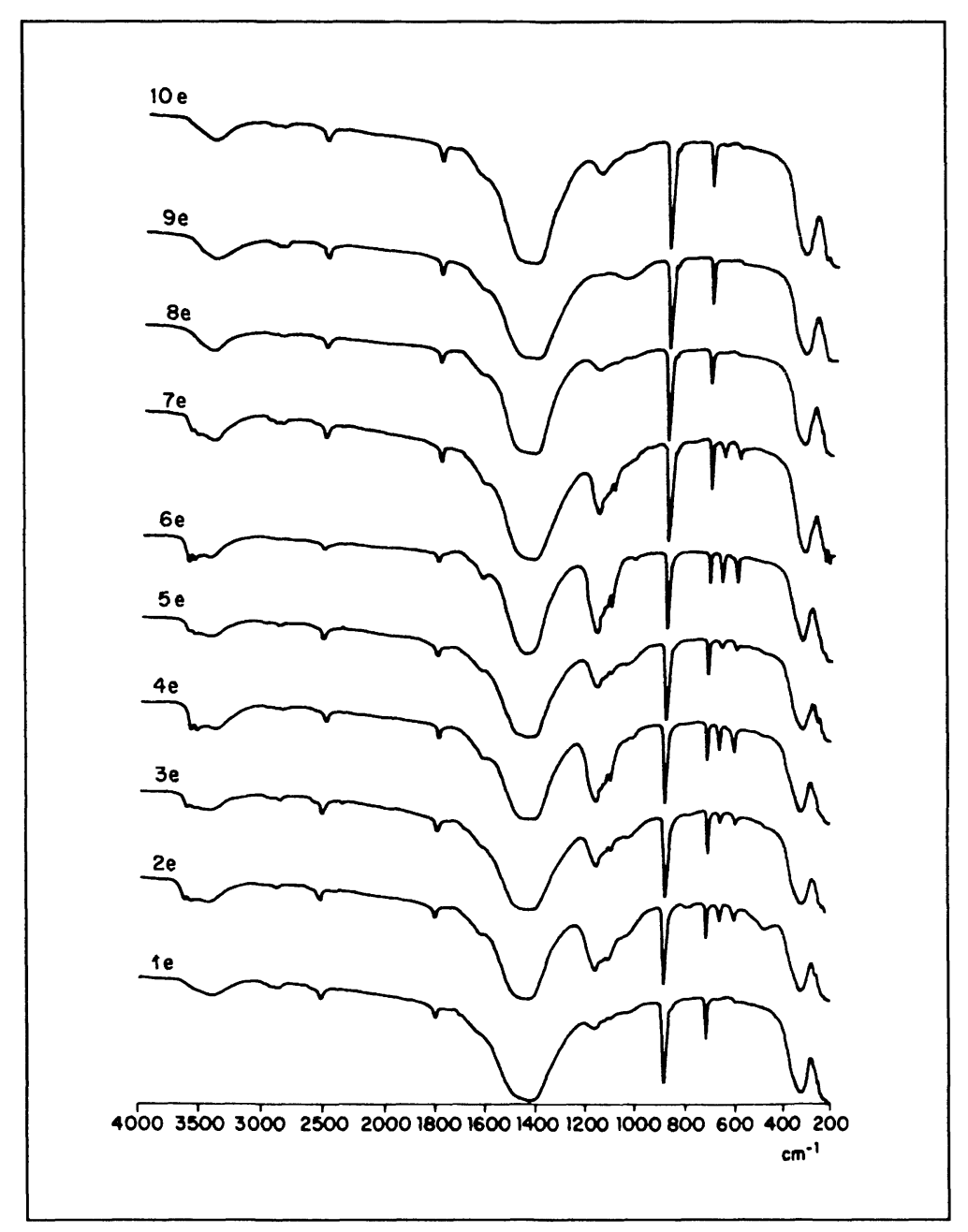

Figura 3.- Espectroscopía IR.

Figure 3.- Spectroscopy IR.

\subsection{Estudio por Microscopía Electrónica de Barrido y Energía Dispersiva de Rayos $\mathrm{X}$}

La técnica de Microscopía Electrónica de Barrido (SEM) ofrece una visión tridimensional de la textura y de la morfología de los cristales, además, por la posibilidad de analizar superficies irregulares, resulta idónea en los estudios de costras de alteración. Por Energía Dispersiva de Rayos X(EDX), se obtiene la composición química semicuantitativa, incluso puntual, de la superficie de la muestra analizada.

\section{* Resultados experimentales}

En las Fotos 1 y 2, se observa el aspecto de las costras superficiales, así como la aparición de cristales, constituidos principalmente por azufre y calcio.

En todos los casos, las capas superficiales están formadas por compuestos de azufre y calcio. Cuando el

\subsection{Study through Scanning Electron Microscopy and $X$ Ray Dispersive Energy}

Scanning Electron Microscopy (SEM) offers a tridimensional view of the texture and morphology of the crystals; furthermore, since it offers the possibility of analysing irregular surfaces. This technique is considered the ideal means for the study of alteration crusts. With $X$ Ray Dispersive Energy (EDX) is possible to determine the semiquantitative chemical composition or even in a local area of the surface of the analysed sample.

\section{* Experimental Results}

In Photos 1 and 2, the aspect of the superficial crusts as well as the crystals formed for the most part of sulphur and calcium can be observed.

In all cases, superficial layers are formed by sulphur and calcium compounds but their concentratios vary 


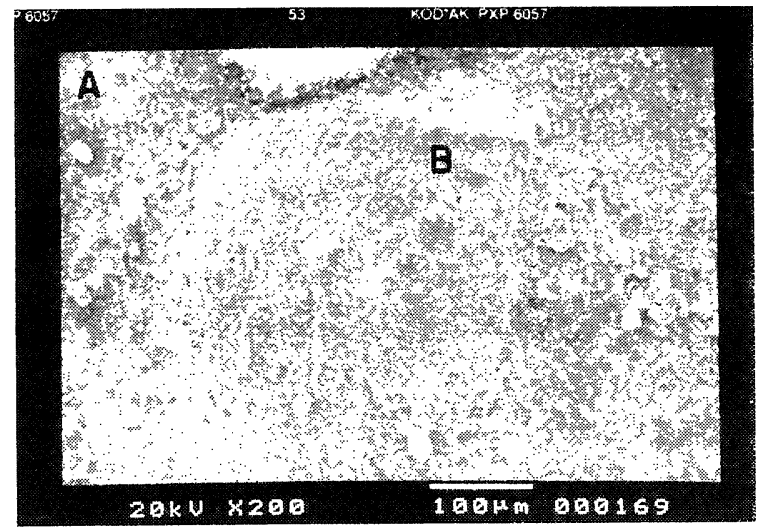

Foto 1.- Distintas zonas pertenecientes a la muestra estudiada: A) Zona constituida por piedra. B) Zona perteneciente a la costra de yeso.

Photo 1.- The different zones belonging to the studied sample: A) Stone. B) Gypsum crystals.

análisis se efectúa en zonas de la preparación exentas de costra, en ellas predomina el calcio sobre el azufre y aparece, en algunos casos, silicio. Esto se debe a que cuando el compuesto analizado es el yeso, la cantidad de azufre y calcio son equivalentes, sin embargo, cuando se analizan zonas en las que eí material pétreo carece de costra, el ión predominante es el calcio, debido a la calcita y suele observarse, en algunos casos, la presencia de silicio, que procede del cuarzo presente en algunas de las muestras.

\section{CONCLUSIORES}

De los resultados obtenidos en los diferentes ensayos efectuados se desprende:

I.- Los materiales pétreos analizados no presentan un deterioro muy pronunciado.

En algunos casos, las muestras más externas presentan una menor porosidad que las muestras extraidas del interior del bloque, lo que indica un taponamiento o colmatación de los poros provocado, posiblemente, por las sales acumuladas no solamente en la capa más superficial del material pétreo, sino también en zonas adyacentes a dicha costra.

Aunque se produzcan estos cambios en la porosidad y en las curvas de distribución de tamaños de poro, los resultados entre piedra exterior e interior no difieren sustancialmente, lo que indica que el deterioro no es muy significativo.

Por otro lado, cuando el hecho anteriormente mencionado no tiene lugar, los valores de porosidad y la distribución de tamaño de poros son semejantes, 10 que implica que el material no presenta cambios

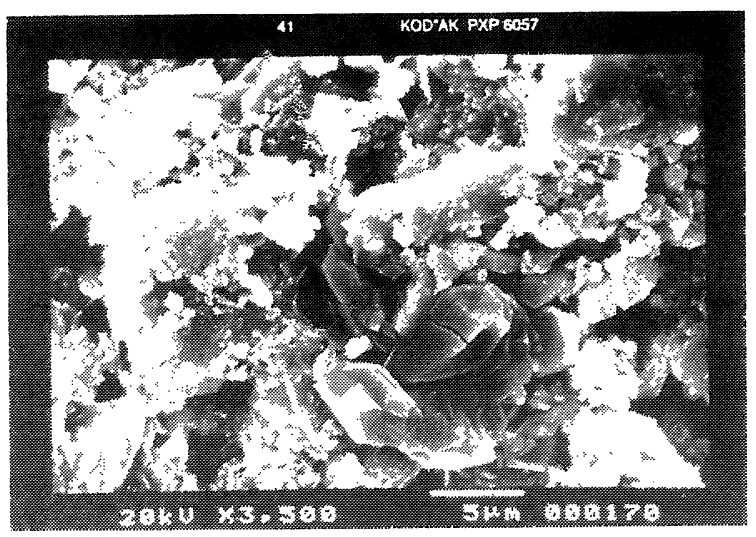

Foto 2.- Aspecto de la costra superficial. Cristales de yeso.

Photo 2.- Aspect of the superficial crust. Gypsum crystals.

depending of the sample. When the analysis was carried out on specimens without crust, the calcium was the predominant ion, followed sulphur anion and, sometimes, silica was also found. While in the analysis of sample taked from the crust (gypsum), the amount of calcium and sulphur was equivalent.

\section{CONCLUSIONS}

From results mentionated above, the following conclusions were obtained:

l. The stone analysed does not show a very strong deterioration.

In any cases, samples from the surface are less porosity than internal ones, which indicates pores are clossed, possibly because of the accumulation of salts not only on the surface layer but also in zones adjoining that crust.

In spite of this variation of porosity and pore size distribution curves distribution. The results obiained from external and internal limestone do not change very much, which indicates that deterioration is not very significant.

On the other hand, when this fact does not occur porosity values and pore size distribution are similar, which implies that material does not bear 
importantes en su estructura interna debidos a problemas de deterioro.

Este hecho queda también reflejado en los estudios realizados mediante difracción de rayos $\mathrm{X}$, en los que no se observan variaciones apreciables entre materiales externos e internos.

II.- Las costras están formadas por yeso. $\mathrm{EL} \mathrm{SO}_{2}$, que proviene esencialmente de la combustión del carbón, por oxidación e hidrólisis y en pesencia del ión $\mathrm{Ca}$ (procedente de la caliza) provoca la formación de costras de yeso, como puede apreciarse en los resultados obtenidos por espectroscopía IR y microscopía electrónica de barrido.

Igualmente, en los análisis con cromatografía iónica se detecta que el ión sulfato es predominante. Así, las mayoría de las muestras presentan en sus zonas exteriores una acumulación de ión sulfato en relación al contenido encontrado en zonas más internas, en las que las concentraciones de los iones analizados son insignificantes.

En las muestras 9e y $9 \mathrm{i}$ no ocurre este hecho. Esto puede ser debido a que estas muestras forman parte de una misma zona escultural, y ambas presentan costras en sus superficies, por lo que el contenido de sales solubles va a estar condicionado por el espesor de las mismas en la parte de material extraído para el ensayo, y de ahí las pequeñas diferencias observadas.

En las muestras $10 \mathrm{e}$ y $10 \mathrm{i}$, pertenecientes también a escultura, existe una clara variación en el espesor de la costra entre unas zonas y otras, por lo que la diferencia en el contenido de sales es significativo. Sin embargo, cuando se eliminan estas costras las variaciones en los valores de porosidad indican que el deterioro no es elevado, ya que apenas existen diferencias en la porosidad y en la distribución de tamaño de poros entre muestras interna y externa. Por lo tanto, como se ha indicado anteriormente, el deterioro se produce sólo superficialmente o en zonas muy próximas a la superficie.

\section{AGRADECIMIENTOS}

Los autores agraden a la Dra. Francisca Puertas Maroto su colaboración, en el asesoramiento y realización de los estudios efectuados por Cromatografía Iónica. any important change in its internal structure due to deterioration problems.

This fact also appears when carrying out the study through $X$ ray diffraction, where no significant differences between inside and outside samples are seen.

II. Crusts are formed with the gypsum. By oxidation and hydrolisis reactions in presence of $\mathrm{Ca}$ (from limestone), the $\mathrm{SO}_{2}$ ion originated in the coal combustion processes provoked the formation of black crust of gypsum, as the results obtained through IR and scanning electron microscopy.

In addition, ion chromatography analysis indicate that sulphate ion is predominant. Thus, most of the external materials show an accumulation of sulphate ion compared to the content found in inner zones where the concentrations of those ions are insignificant.

In samples $9 e$ and $9 i$ this fact does not take place, possibly because these specimens belong to the same sculpture area, and both have crusts in their surface, which means that the content of soluble salts is going to be conditionned by the thickness of the crusts in specimens extracted for that test. This is the origin of the small differences observed.

In samples 10 and $10 i$, also belonging to the sculpture, there is a clear variation in the thickness of the crust from one area to another, which means that the differences in salts content is significant. However, when removing the crusts, variations as for porosity values indicate there is not much deterioration, since there are just slight differences in porosity and in pore size distribution between internal and external samples. Therefore, as stated before, deterioration occurs only in superficial or close to the surface areas.

\section{ACKNOWLEDGEMENTS}

Authors thank Dra. Francisca Puertas Maroto for her collaboration and for her advise on the Ion Chromatography study.

\section{BIBLIOGRAFÍA}

(1) AMOROSO, G., FASSINA, V.: (1983). "Stone decay and conservation" pp 449.

(2) LORUSSO, S., TROILI, M., BUONOCORE, F. y MARABELLI, M.: (1997). "Air pollution and historic monuments". 4th International Symposium on the Conservation of Monuments in the Mediterranean Basin", Rodas Grecia. 
(3) FITZNER, B.: (1993). "Porosity properties and weathering behaviour of natural stones methology and example". Second Course C.U.M. University School of Monument Conservation: Stone material in monuments: Diagnosis and Conservation. Heraklion.

(4) MAMILLAN, M.:(1990). “Methodes d'evaluation des desgradations des monuments en pierre". Analytical methodologie for the investigation of damaged stone. Pavia.

(5) BOEKE, H., GOEKTUERK, H., CANER-SALTIK, E.N: (1997). "The control of gypsum formation on calcareous stone surface". 4th International Symposium on the Conservation of Monuments in the Mediterranean Basin", Rodas, Grecia.

(6) GAURI, K.L., PUNURU, A.R.: (1989). "Characterization and durability of limestones determined through mercury intrusion porosimetry". 1 st International Symposium on the Conservation of Monuments in the Mediterranean Basin, Bari, Italia.

(7) POSCHOLD, K: (1989). "Pore structure and properties of marbles". 1st International Symposium on the Conservation of Monuments in the Mediterranean Basin", Bari, Italia.

(8) GARCÍA PASCUA, N., SÁNCHEZ DE ROJAS, M.I., FRÍAS M.: (1995). "Study of porosity and physical properties as methods to establish the effectiveness of treatments used in two different spanish stones: limestone and sadstone". International Colloquium Methods of Evaluating Products for the Conservation of Porous Building materials in Monuments. Rome. Italia.

\section{Publicación del Instituto Eduardo Torroja - CSIC}

\section{Número monográfico de INFORMES}

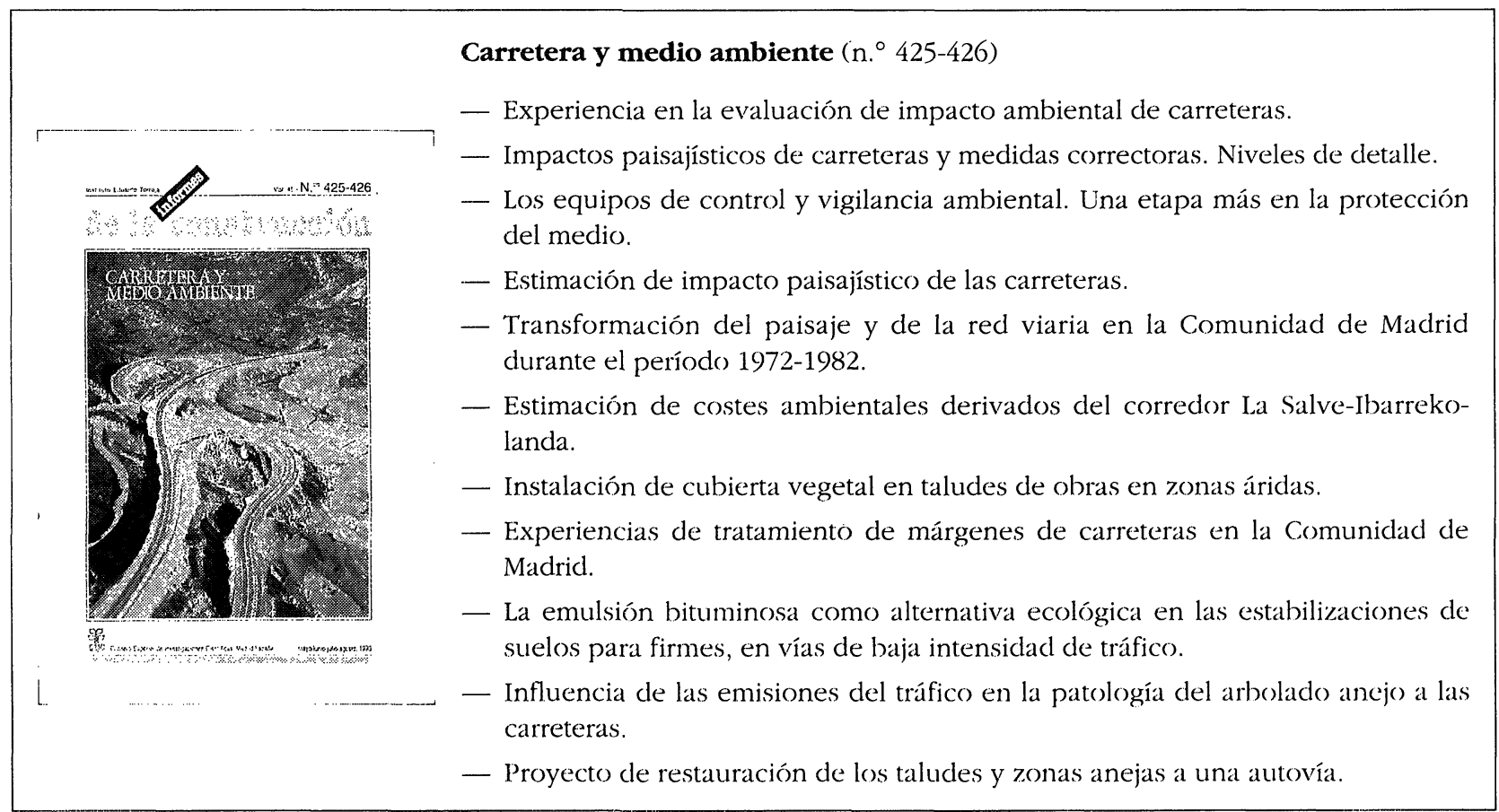

